\title{
CREB3L2/PPARG Fusion Gene
}

National Cancer Institute

\section{Source}

National Cancer Institute. CREB3L2/PPARG Fusion Gene. NCI Thesaurus. Code C156142.

A fusion gene that results from a chromosomal translocation $\mathrm{t}(3 ; 7)(\mathrm{p} 25 ; \mathrm{q} 34)$ which fuses exon 1 and 2 of the CREB3L2 gene with exons $1-6$ of the PPARG gene. This rearrangement is associated with thyroid follicular carcinoma. 